\title{
Mechanisms of the Enhanced Contractile Response to Phenylephrine in Thoracic Aorta Isolated from Rats with Dietary Magnesium Deficiency
}

\author{
Hideaki Sakaguchi and Akira Nishio* \\ Department of Veterinary Pharmacology, Faculty of Agriculture, Kagoshima University, Kagoshima 890, Japan \\ Received September 24, $1993 \quad$ Accepted January 18, 1994
}

\begin{abstract}
The mechanisms underlying the enhanced contractile response to phenylephrine (PE) and increased susceptibility to nifedipine of de-endothelialized thoracic aorta isolated from rats with dietary magnesium deficiency (Mg-deficient rats) were examined by functional and radioligand binding studies. Enhanced PE-induced contractions and increased susceptibility to nifedipine in $\mathrm{Mg}$-deficient rats were not observed in the presence of $10 \mu \mathrm{M} \mathrm{H} 7$. PE significantly decreased the $\mathrm{K}_{\mathrm{D}}$ value without changing $\mathrm{B}_{\max }$ in the binding of [ $\left.{ }^{3} \mathrm{H}\right] \mathrm{PN} 200-110$ to de-endothelialized aortic strips. The $\mathrm{K}_{\mathrm{D}}$ value obtained in the $\mathrm{Mg}$-deficient rats was significantly smaller than that in the controls. Nifedipine displaced the binding of $\left.{ }^{3} \mathrm{H}\right] \mathrm{PN} 200-110$ concentration-dependently, and the $\mathrm{pK}_{\mathrm{i}}$ value in $\mathrm{Mg}$-deficient rats was significantly larger than that in the controls. A combination of PE and $\mathrm{H} 7$ abolished this difference. These results indicate that the modulation of L-type $\mathrm{Ca}^{2+}$ channels via the stimulation of $\alpha_{1}$-adrenoceptors may be involved in the enhancement of vasoconstriction and increased susceptibility to nifedipine in aortas isolated from Mg-deficient rats. The H7-sensitive mechanisms may play an important role in these phenomena.
\end{abstract}

Keywords: Mg-deficient rat, Phenylephrine, Nifedipine, $\left[{ }^{3} \mathrm{H}\right] \mathrm{PN} 200-110$ binding, $\mathrm{H} 7$

It is well known that magnesium ions $\left(\mathrm{Mg}^{2+}\right)$ influence the contractile response of isolated blood vessels to some endogenous vasoactive agents such as norepinephrine and serotonin (1). These experiments showed that low concentrations of $\mathrm{Mg}^{2+}$ in physiological salt solution enhance $\mathrm{Ca}^{2+}$-entry into smooth muscle cells, resulting in enhanced muscular contraction. An ex vivo study using rats with dietary magnesium deficiency has shown that an enhanced contractile response to norepinephrine is observed in the isolated thoracic aorta after $\mathbf{3 0}$ days, but not after 15 days, while hypomagnesemia is observed after only 5 days (2). These results suggest that there are differences between the effects of in vivo dietary magnesium $(\mathrm{Mg})$ deficiency (at day 30) and in vitro $\mathrm{Mg}^{2+}$ depletion on the mechanisms of the enhanced contractile response of aortas to vasoactive agents.

Our previous studies showed that in thoracic aorta isolated from $\mathrm{Mg}$-deficient rats, enhanced $\mathrm{Ca}^{2+}$ influx via $\mathrm{L}$ type $\mathrm{Ca}^{2-}$ channels resulted in enhanced norepinephrineand phenylephrine (PE)-induced contractions $(3,4)$, and that dietary $\mathrm{Mg}$-deficiency increased the maximal density $\left(B_{\max }\right)$ of $\left[{ }^{3} \mathrm{H}\right] \mathrm{PN} 200-110$ specific binding, but not the $B_{\max }$

${ }^{*}$ To whom correspondence should be addressed. of $\left[{ }^{3} \mathrm{H}\right]$ prazosin, and did not alter the binding affinities of either ligand to aortic membranes (4). These results suggest that an increase in the density of L-type $\mathrm{Ca}^{2+}$ channels is involved in the enhancement of the contractile response to $\mathrm{PE}$ in thoracic aorta from $\mathrm{Mg}$-deficient rats.

However, it is well known that $\mathbf{L}$-type $\mathrm{Ca}^{2+}$ channels exist in different conformational states (i.e., closed, open and inactivated) and that each state has a different affinity for dihydropyridines (5). It therefore seems important to correlate binding data with functional data.

The present study was undertaken to clarify the mechanisms underlying the enhanced contractile response to $\mathrm{PE}$ and increased susceptibility to nifedipine in thoracic aorta isolated from rats with dietary $\mathrm{Mg}$ deficiency, using functional and radioligand binding studies.

\section{MATERIALS AND METHODS}

\section{Animals}

Adult male Wistar rats (7- to 9-week-old) were fed a Mg-deficient diet $\left(\mathrm{Mg}^{2+}: 0.001 \%\right)$ for 30 days. A control group received a normal diet $\left(\mathrm{Mg}^{2+}: 0.07 \%\right)$. The composition of the purified experimental diet has been described in detail in a previous paper (2). The rats were pair-fed 
and allowed free access to deionized water. Each rat was housed individually in a stainless steel cage at an ambient temperature of $22-24^{\circ} \mathrm{C}$ under a 12 -hr light-dark cycle.

\section{Functional study}

After an experimental period of 30 days, each rat was decapitated and the thoracic aorta was removed immediately. The aorta was cleaned of all fat and connective tissue and cut into rings about 2-mm-wide. Each ring was mounted in an organ bath containing $10 \mathrm{ml}$ physiological salt solution (PSS) with the following composition: 119 $\mathrm{mM} \mathrm{NaCl}, 4.7 \mathrm{mM} \mathrm{KCl}, 2.5 \mathrm{mM} \mathrm{CaCl}_{2}, 1.2 \mathrm{mM} \mathrm{MgCl}$, $1.2 \mathrm{mM} \mathrm{KH}_{2} \mathrm{PO}_{4}, 25 \mathrm{mM} \mathrm{NaHCO}$ and $10 \mathrm{mM}$ glucose. The organ bath solution was maintained at $37^{\circ} \mathrm{C}$ and gassed with a $95 \% \mathrm{O}_{2}$ and $5 \% \mathrm{CO}_{2}$ gas.

A $10-\mathrm{mN}$ resting tension, which was optimal for inducing the maximal contraction in both aortas, was applied to each aortic strip, and an equilibration period of $2 \mathrm{hr}$ was allowed before the aortic ring was exposed to drugs. The isometric muscle tension was recorded with a forcetransducer (TB-611T; Nihon Kohden Kogyo Co., Tokyo) connected to a polygraph (AP-621G, Nihon Kohden Kogyo Co.). Cumulative concentration-response curves were obtained by a stepwise increase in the concentration of the agonists; additions were made as soon as a steady response was obtained with the preceding concentration. When antagonists were used, each was added to the organ bath $30 \mathrm{~min}$ (nifedipine) or $90 \mathrm{~min}(\mathrm{H} 7)$ before the concentration-response curves of the agonists were obtained.

In both functional and binding studies, we used preparations denuded of their endothelium to avoid the effects of this tissue (6). To remove the endothelium, the intimal surface was rubbed gently with a swab wetted with PSS. The absence of endothelium was verified by a lack of relaxation when acetylcholine was added.

\section{Binding study}

The binding of $\left[{ }^{3} \mathrm{H}\right] \mathrm{PN} 200-110$ to de-endothelialized aortic strips was determined by the method of Morel and Godfraind (7). Strips of aorta $(0.8-1.0 \mathrm{mg})$ were incubated in PSS with $\left.{ }^{3} \mathrm{H}\right] \mathrm{PN} 200-110(0.02-0.75 \mathrm{nM})$ for 90 min at $37^{\circ} \mathrm{C}$ in the dark. When the effects of PE or $\mathrm{KCl}$ were examined, these were added to the PSS during the last $30 \mathrm{~min}$ of incubation. At the end of incubation, each strip was washed 3 times with ice-cold PSS and then dried on filter paper, weighed and dissolved in $0.1 \mathrm{ml}$ of a mixture of perchloric acid : hydrogen peroxide $(1: 1)$. Radioactivity was counted by a liquid scintillation counter (LSC-3050; Aloka Co., Tokyo). To determine nonspecific binding, $3 \mu \mathrm{M}$ nifedipine was included in the incubation medium. The difference between total binding and non-specific binding was taken as specific binding.

\section{Analysis of parameters}

The dissociation constant $\left(\mathrm{K}_{\mathrm{D}}\right)$, the maximal density of specific binding sites $\left(B_{\max }\right)$ and the Hill coefficient were determined by Scatchard analysis using an equilibrium binding data analysis computer program (8). In displacement studies, the $\mathrm{IC}_{50}$ value (the concentration of a $\mathrm{Ca}^{2}$ channel antagonist inducing a $50 \%$ inhibition of the binding of $\left[{ }^{3} \mathrm{H}\right] \mathrm{PN} 200-110$ ) was determined by regression analysis, using a Hofstee plot, and the inhibitor constant $\left(\mathrm{K}_{\mathrm{i}}\right)$ was calculated by the computer program (8).

\section{Statistical analyses}

The data were expressed as the mean \pm S.E. and were analyzed statistically by Student's $t$-test and Sheffé's test for comparisons involving three or more values. Unless stated otherwise, $\mathbf{n}$ refers to the number of animals. A probability of less than 0.05 was considered to indicate a significant difference.

\section{Drugs}

Drugs used were: (-)-phenylephrine hydrochloride (Wako Pure Chemical Industries, Ltd., Osaka), nifedipine (Sigma Chemical Co., St. Louis, MO, USA), (+)-[ $\left.{ }^{3} \mathrm{H}\right]-$ PN 200-110 (83 Ci/mmol; Amersham, Tokyo) and 1-(5isoquinolinesulfonyl)-2-methylpiperazine dihydrochloride (H7) (Research Biochemicals Inc., Natic, MA, USA).

\section{RESULTS}

\section{General observations}

Even though the control and $\mathrm{Mg}$-deficient rats were pair-fed, the body weight gain in $\mathrm{Mg}$-deficient rats $(57.56 \pm 7.52 \mathrm{~g}, \mathbf{n}=15)$ was significantly smaller than that in the controls $(113.9 \pm 6.31 \mathrm{~g}, \mathrm{n}=15)$. However, the wet weight of thoracic aortas in $\mathrm{Mg}$-deficient rats $(51 \pm 4 \mathrm{mg}$, $\mathrm{n}=23$ ) was not significantly different from that in the controls ( $51 \pm 3 \mathrm{mg}, \mathrm{n}=23$ ). As previously reported (2), there were no morphologocal changes in aortas from $\mathrm{Mg}$ deficient rats. Plasma $\mathrm{Mg}, \mathrm{Ca}$, potassium (K) and sodium $\mathrm{Na}$ ) were determined by an atomic absorption spectrophotometer (170-50A; Hitachi, Ltd., Tokyo) (9). Plasma magnesium levels in the control $(n=8)$ and Mg-deficient $(n=8)$ rats, after 30 days, were $1.75 \pm 0.07 \mathrm{mEq} / 1$ and $0.52 \pm 0.04 \mathrm{mEq} / 1$, respectively. Plasma levels of $\mathrm{Ca}, \mathrm{K}$ and $\mathrm{Na}$ were $4.96 \pm 0.08 \mathrm{mEq} / 1,5.54 \pm 0.50 \mathrm{mEq} / 1$ and $148.3 \pm 0.9 \mathrm{mEq} / 1$ in the $\mathrm{Mg}$-deficient rats $(\mathrm{n}=8)$ after 30 days. Except for magnesium, these values were not significantly different from those of the controls $(n=8)$.

\section{Contractile responses to $P E$ and $K C l$}

Figure 1 shows the concentration-response curves for PE, a selective $\alpha_{1}$-agonist, in thoracic aortas isolated from the control and $\mathrm{Mg}$-deficient rats. Contractile responses 


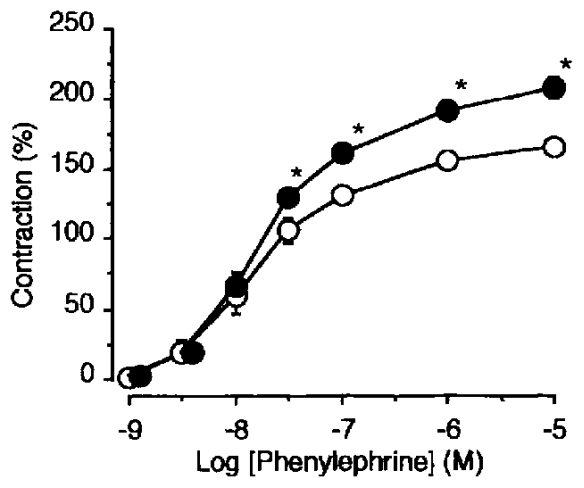

Fig. 1. Concentration-response curves for phenylephrine in de-endothelialized thoracic aortas isolated from the control $(O)$ and $\mathrm{Mg}$ deficient (O) rats. Each point represents the mean value from 6-7 rats \pm S.E. Contractions induced by $30 \mathrm{mM} \mathrm{KCl}$ were taken as $100 \%$; mean absolute values were $7.0 \pm 0.7 \mathrm{mN}$ in $\mathrm{Mg}$-deficient rats and $7.2 \pm 0.6 \mathrm{mN}$ in control rats. There was no significant difference between the two values. * Significantly different from the corresponding controls $(P<0.05)$.

to $\mathrm{PE}\left(3 \times 10^{-8}-10^{-5} \mathrm{M}\right)$ were significantly greater in $\mathrm{Mg}$ deficient rats than in the controls. However, there was no significant difference in the $\mathrm{pD}_{2}$ value between the control (7.64 \pm 0.11$)$ and $\mathrm{Mg}$-deficient rats (7.63 \pm 0.55$)$. There was no significant difference in contractile response to $\mathrm{KCl}(15-60 \mathrm{mM})$ between the control and $\mathrm{Mg}$-deficient rats. The $\mathrm{pD}_{2}$ values for $\mathrm{KCl}$ were $1.65 \pm 0.01$ in $\mathrm{Mg}$ deficient rats and $1.69 \pm 0.03$ in the controls.

\section{Effects of nifedipine on the contractile responses to $P E$ and $\mathrm{KCl}$}

The inhibitory effects of nifedipine on the contractile response to $\mathrm{PE}$ in thoracic aortas isolated from the control and $\mathrm{Mg}$-deficient rats are shown in Fig. 2. Nifedipine $(0.1-10 \mathrm{nM})$ inhibited the contractile response to $\mathrm{PE}$ in
Table 1. $\mathrm{pIC}_{50}$ values for nifedipine in the contractile response to phenylephrine (PE) with or without $\mathrm{H} 7$ in isolated thoracic aortas

\begin{tabular}{ccc}
\hline & PE $10 \mu \mathrm{M}$ & PE $10 \mu \mathrm{M}+\mathrm{H} 710 \mu \mathrm{M}$ \\
\hline Control & $\begin{array}{c}8.12 \pm 0.31 \\
(\mathrm{n}=8)\end{array}$ & $\begin{array}{c}7.90 \pm 0.14 \\
(\mathrm{n}=6)\end{array}$ \\
Mg-deficient & $\begin{array}{c}9.21 \pm 0.23^{\mathrm{a}} \\
(\mathrm{n}=8)\end{array}$ & $\begin{array}{c}7.92 \pm 0.33^{\mathrm{b}} \\
(\mathrm{n}=6)\end{array}$ \\
\hline
\end{tabular}

${ }^{a}$ Significantly different from the control $(\mathrm{P}<0.05)$. ${ }^{\mathrm{b}}$ Significantly different from $\mathrm{H} 7$-non-treated strips $(\mathrm{P}<0.05)$. $n$, Number of rats used.

both groups. The degree of inhibition with nifedipine was significantly greater in $\mathrm{Mg}$-deficient rats than in the controls. As shown in Table 1, the $\mathrm{pIC}_{50}$ value of nifedipine on the contractile response to $10 \mu \mathrm{M}$ PE was significantly greater in $\mathrm{Mg}$-deficient rats than in the controls. However, the inhibitory effect of nifedipine on contractions induced by $60 \mathrm{mM} \mathrm{KCl}$ in $\mathrm{Mg}$-deficient rats was not significantly different from that in the controls; the $\mathrm{pIC}_{50}$ value of nifedipine in the control and $\mathrm{Mg}$-deficient rats was $9.05 \pm 0.08$ and $9.12 \pm 0.08$, respectively.

\section{Effects of $\mathrm{H} 7$ on the contractile response to $\mathrm{PE}$}

Figure 3 shows the concentration-response curves for $\mathrm{PE}$ in thoracic aortas isolated from the control and $\mathrm{Mg}$ deficient rats in the presence or absence of $10 \mu \mathrm{M} \mathrm{H} 7$ (a protein kinase $\mathrm{C}$ inhibitor). In the absence of $\mathrm{H} 7$, PE-induced contractions in $\mathrm{Mg}$-deficient rats were significantly greater than those in the controls, as in Fig. 1. In the presence of $\mathbf{H 7}$, however, the contractile response to $\mathrm{PE}$ was not significantly different in the control and $\mathrm{Mg}$ deficient rats.
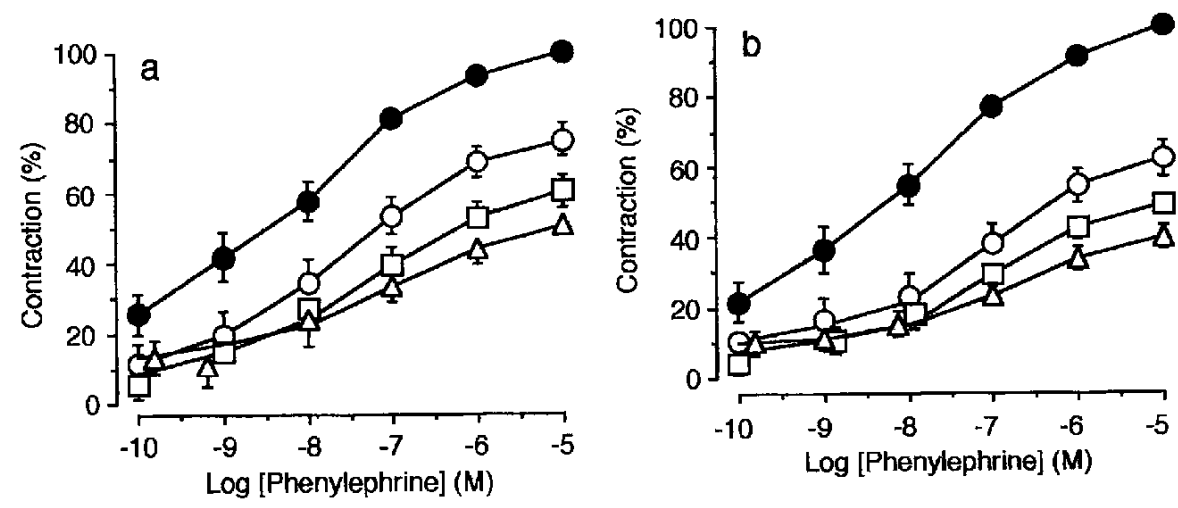

Fig. 2. Effects of nifedipine on the contractile response to phenylephrine (PE) (O) in de-endothelialized thoracic aortas isolated from the control (a) and $\mathrm{Mg}$-deficient (b) rats. Nifedipine $(\bigcirc, 0.1 \mathrm{nM} ; \square, 1.0 \mathrm{nM} ; \Delta, 10 \mathrm{nM}$ ) was added to the organ bath 30 min before the concentration-response curves for $\mathrm{PE}$ were obtained. Contractions induced by $10 \mu \mathrm{M}$ PE were taken as $100 \%$. Each point represents the mean of 8 rats \pm S.E. 


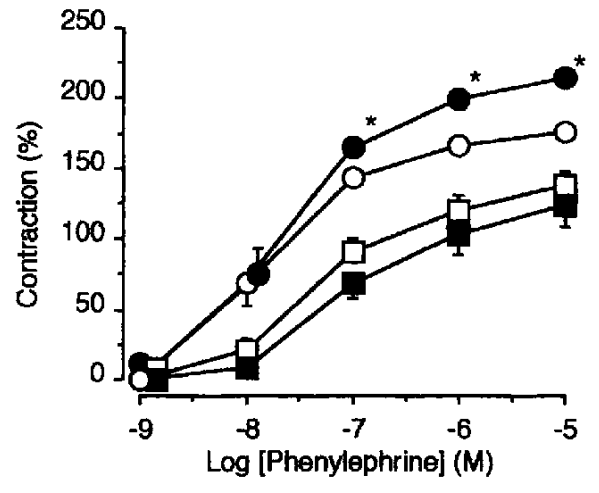

Fig. 3. Concentration-response curves for phenylephrine (PE) in de-endothelialized thoracic aortas isolated from the control $(\bigcirc, \square)$ and $\mathrm{Mg}$-deficient $(\mathbf{O}, \square)$ rats in the presence $(\square, \square)$ or absence $(\circlearrowleft$, D) of $10 \mu \mathrm{M} \mathrm{H} 7$. Contractions induced by $30 \mathrm{mM} \mathrm{KCl}$ were taken $100 \%$; mean absolute values were $7.4 \pm 0.5 \mathrm{mN}$ in $\mathrm{Mg}$-deficient rats and $7.6 \pm 0.5 \mathrm{mN}$ in control rats. There was no significant difference between the two values. $\mathrm{H} 7$ was added to the organ bath $90 \mathrm{~min}$ before the concentration-response curves for PE were obtained. Each point represents the mean of 6 rats \pm S.E. * Significantly different from the corresponding controls $(\mathrm{P}<0.05)$.

\section{Effects of nifedipine on PE-induced contraction in the presence of $\mathrm{H7}$}

Figure 4 shows the inhibitory effects of nifedipine on PE-induced contractions in thoracic aortas isolated from control and $\mathrm{Mg}$-deficient rats in the presence of $10 \mu \mathrm{M}$ $\mathrm{H} 7$. In the presence of $\mathrm{H} 7$, there was no significant difference in the inhibitory effect of nifedipine between the control and $\mathrm{Mg}$-deficient rats. As shown in Table 1, the $\mathrm{pIC}_{50}$ value of nifedipine in $\mathrm{Mg}$-deficient rats was not significantly different from that in the controls, and it was significantly smaller than that observed in the absence of H7.

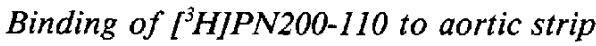

The specific binding of $\left[{ }^{3} \mathrm{H}\right] \mathrm{PN} 200-110$ to an aortic strip was determined in the control and $\mathrm{Mg}$-deficient rats. In physiological salt solution (resting state), $\left[{ }^{3} \mathrm{H}\right] \mathrm{PN} 200-$ 110 bound with high affinity and in a saturable manner (Fig. 5a). Scatchard plots of the specific binding were linear in both groups (Fig. $5 \mathrm{~b}$ ), indicating a single class of binding sites. The $K_{D}$ value obtained from $\mathrm{Mg}$-deficient rats was not significantly different to that from the controls; however, $B_{\max }$ was significantly larger in $\mathrm{Mg}$ deficient rats than in the controls (Table 2).

In the presence of $10 \mu \mathrm{MPE}$ or $60 \mathrm{mM} \mathrm{KCl}$, the specific binding of $\left[{ }^{3} \mathrm{H}\right] \mathrm{PN} 200-110$ increased without any change in the non-specific binding in both groups, and the Scatchard plots were linear in both cases (data not shown), indicating a single class of binding sites. Calculated $K_{D}$ and $\mathrm{B}_{\max }$ values are shown in Table 2. $\mathrm{PE}$ and $\mathrm{KCl}$ significantly decreased $K_{D}$, but did not significantly affect $B_{\max }$ in both groups. In the presence of $P E$, the $K_{D}$ value was significantly smaller in $\mathrm{Mg}$-deficient rats than in the controls. This difference was not observed with $60 \mathrm{mM} \mathrm{KCl}$.

\section{Effects of nifedipine on $\left[{ }^{3} \mathrm{H}\right] P N 200-110$ binding to aortic strip}

The inhibitory effects of nifedipine on $\left[{ }^{3} \mathrm{H}\right] \mathrm{PN} 200-110$ binding to aortic strips isolated from the control and $\mathrm{Mg}$ deficient rats were investigated. In the resting state, nifedipine displaced the specific binding of $\left[{ }^{3} \mathrm{H}\right] \mathrm{PN} 200-110$ in a concentration-dependent manner (Fig. 6), and the Hofstee plots were linear (data not shown). There was no significant difference in the $\mathrm{pK}_{\mathrm{i}}$ of nifedipine between the control and $\mathrm{Mg}$-deficient rats (Table 3).

In the presence of $10 \mu \mathrm{MPE}$ or $60 \mathrm{mM} \mathrm{KCl}$, the displacement curves for nifedipine were shifted to the left
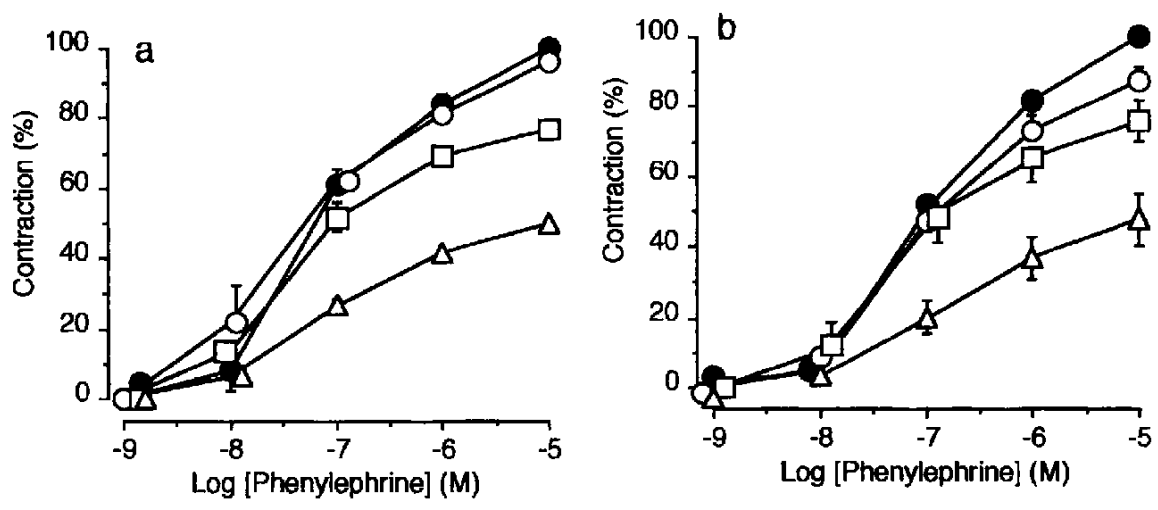

Fig. 4. Effects of nifedipine on the contractile response to phenylephrine (PE) (O) in de-endothelialized thoracic aortas isolated from the control (a) and Mg-deficient (b) rats in the presence of $10 \mu \mathrm{M} \mathrm{H7}$. H7 was added to the organ bath 90 min before the concentration-response curves for PE were obtained. Nifedipine $(O, 0.1 \mathrm{nM} ; \square, 1.0 \mathrm{nM} ; \Delta, 10 \mathrm{nM})$ was added to the organ bath $30 \mathrm{~min}$ before the concentration-response curves for PE were obtained. Contractions induced by $10 \mu \mathrm{M}$ PE in the presence of $\mathrm{H} 7$ were taken as $100 \%$. Each point represents the mean of 6 rats \pm S.E. 

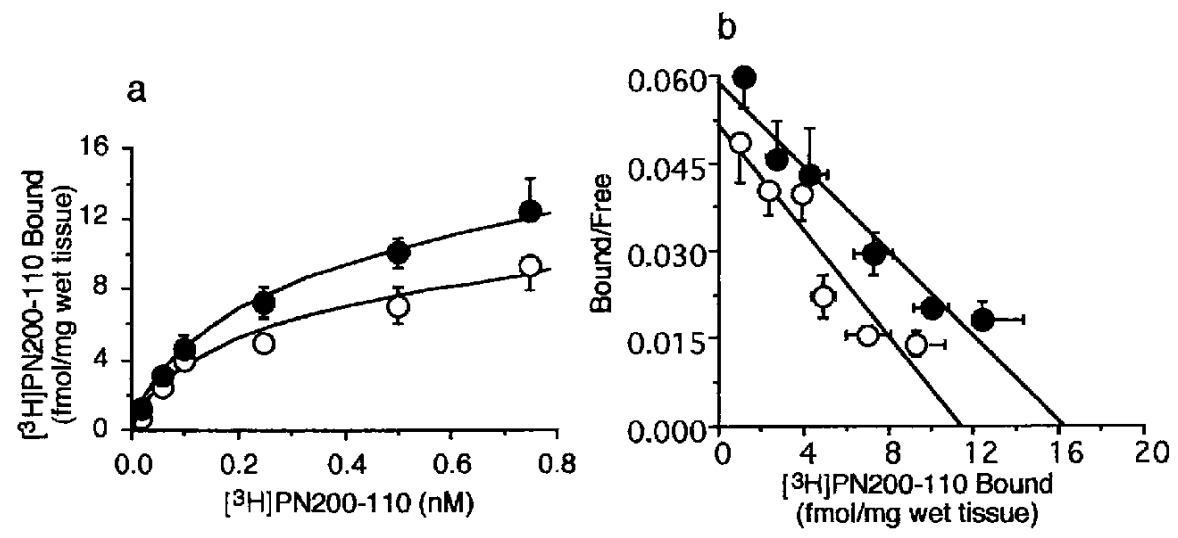

Fig. 5. Saturation curves (a) and Scatchard plots (b) of the specific binding of $\left[{ }^{3} \mathrm{H}\right] \mathrm{PN} 200-110$ to de-endothelialized thoracic aortas isolated from the control $(\bigcirc)$ and $\mathrm{Mg}$-deficient $(O)$ rats in physiological salt solution. Each point represents the mean of 8 rats \pm S.E.

Table 2. Characteristics of $\left[{ }^{3} \mathrm{H}\right] \mathrm{PN} 200-110$ binding to isolated thoracic aortas

\begin{tabular}{lccccc}
\hline & \multicolumn{2}{c}{$\mathrm{K}_{\mathrm{D}}(\mathrm{nM})$} & & \multicolumn{2}{c}{$\mathrm{B}_{\max }$ (fmol/mg wet tissue) } \\
\cline { 2 - 3 } & Control & Mg-deficient & & Control & Mg-deficient \\
\hline Vehicle & $0.234 \pm 0.016$ & $0.258 \pm 0.011$ & & $11.4 \pm 1.4$ & $15.8 \pm 1.2^{\mathrm{a}}$ \\
$\mathrm{PE} 10 \mu \mathrm{M}$ & $0.151 \pm 0.009^{\mathrm{b}}$ & $0.106 \pm 0.007^{\mathrm{a}, \mathrm{b}}$ & & $15.2 \pm 1.3$ & $16.1 \pm 1.3$ \\
$\mathrm{KCl} 60 \mathrm{mM}$ & $0.136 \pm 0.023^{\mathrm{b}}$ & $0.140 \pm 0.014^{\mathrm{b}}$ & & $17.9 \pm 3.5$ & $18.7 \pm 3.0$ \\
\hline
\end{tabular}

Each value represents the mean of 5-8 rats \pm S.E. PE, phenylephrine. ${ }^{2}$ Significantly different from the corresponding control $(\mathrm{P}<0.05)$. ${ }^{b}$ Significantly different from the corresponding vehicle $(\mathrm{P}<0.05)$.

(Fig. 6), and the Hofstee plots were linear in both groups (data not shown). As shown in Table 3, PE and $\mathrm{KCl}$ significantly increased the $\mathrm{pK}_{\mathrm{i}}$ for nifedipine in both groups. In the presence of $\mathrm{PE}$, the $\mathrm{pK}_{\mathrm{i}}$ value in $\mathrm{Mg}$-deficient rats was significantly larger than that in the controls. This difference was not observed with $60 \mathrm{mM} \mathrm{KCl}$.

Effects of $\mathrm{H} 7$ on [ $^{3} \mathrm{HJPN} 200-110$ binding to aortic strip

The effects of $\mathrm{H} 7$ on $\left[{ }^{3} \mathrm{H}\right] \mathrm{PN} 200-110$ specific binding were investigated in PE-stimulated aortas. Scatchard
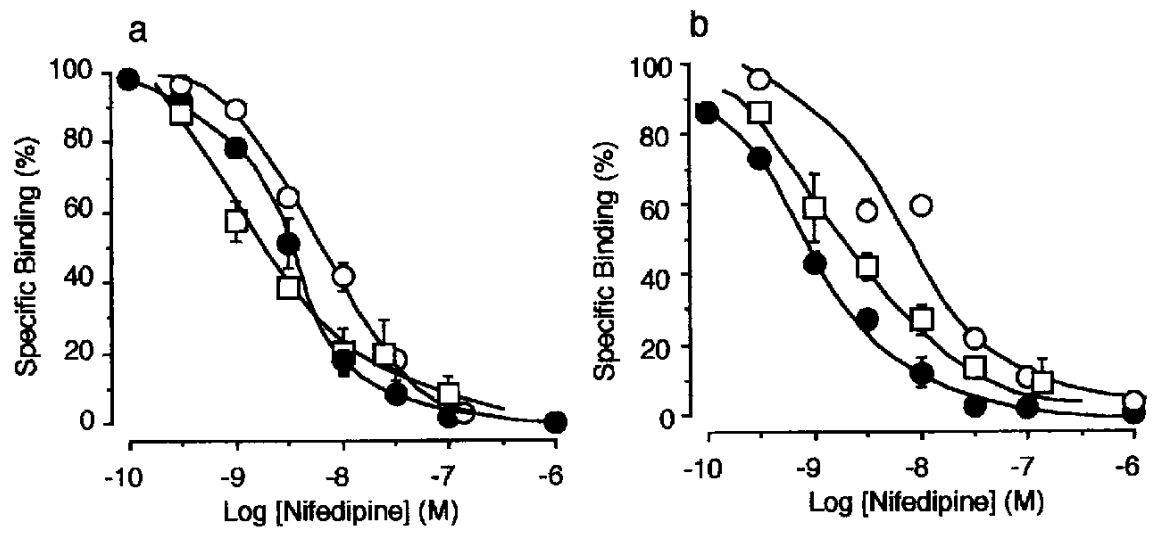

Fig. 6. Effects of nifedipine on the specific binding of $\left[{ }^{3} \mathrm{H}\right] \mathrm{PN} 200-110$ to de-endothelialized thoracic aortas isolated from the control (a) and $\mathrm{Mg}$-deficient (b) rats. Binding studies were carried out with $0.2 \mathrm{nM}\left[{ }^{3} \mathrm{H}\right] \mathrm{PN} 200-110$. Aortic strips were incubated for $60 \mathrm{~min}$ in physiological salt solution and further incubated for $30 \mathrm{~min}$ in solution containing vehicle (O), $10 \mu \mathrm{M}$ PE (O) or $60 \mathrm{mM} \mathrm{KCl}(\square)$. Each point represents the mear of 4-5 rats \pm S.E. 
Table 3. $\mathrm{pK}_{\mathrm{i}}$ values for nifedipine in $\left.{ }^{3} \mathrm{H}\right] \mathrm{PN} 200-110$ binding to isolated thoracic aortas in the presence of vehicle, $\mathrm{PE}$ or $\mathrm{KCl}$

\begin{tabular}{lccc}
\hline & Vehicle & PE 10 $\mu \mathrm{M}$ & $\mathrm{KCl} \mathrm{60mM}$ \\
\hline Control & $\begin{array}{c}8.28 \pm 0.05 \\
(\mathrm{n}=4)\end{array}$ & $\begin{array}{c}8.69 \pm 0.07^{\mathrm{b}} \\
(\mathrm{n}=5)\end{array}$ & $\begin{array}{c}9.00 \pm 0.04^{\mathrm{b}} \\
(\mathrm{n}=4)\end{array}$ \\
Mg-deficient & $\begin{array}{c}8.36 \pm 0.11 \\
(\mathrm{n}=4)\end{array}$ & $\begin{array}{c}9.54 \pm 0.04^{\mathrm{a}} \mathrm{b} \\
(\mathrm{n}=5)\end{array}$ & $\begin{array}{c}9.03 \pm 0.07^{\mathrm{b}} \\
(\mathrm{n}=4)\end{array}$ \\
\hline
\end{tabular}

a Significantly different from the control $(\mathrm{P}<0.05)$. ${ }^{\mathrm{b}}$ Significantly different from the vehicle $(P<0.05)$. $P E$, phenylephrine; $n$, number of rats used.

Table 4. Effects of $\mathbf{H 7}$ on $\left[{ }^{1} \mathrm{H}\right] \mathrm{PN} 200-110$ binding to isolated thoracic aortas

\begin{tabular}{cccc}
\hline & $\begin{array}{c}\mathbf{K}_{\mathrm{D}} \\
(\mathrm{nM})\end{array}$ & $\begin{array}{c}\mathrm{B}_{\max } \\
(\mathrm{fmol} / \mathrm{mg} \text { wet tissue) }\end{array}$ \\
\hline $\mathrm{PE} 10 \mu \mathrm{M}+\mathrm{H} 710 \mu \mathrm{M}$ & & \\
Control $\quad(\mathrm{n}=4)$ & $0.194 \pm 0.014$ & $15.7 \pm 1.8$ \\
Mg-deficient & $(\mathrm{n}=4)$ & $0.188 \pm 0.012$ & $19.2 \pm 1.2$ \\
\hline
\end{tabular}

PE, phenylephrine; $n$, number of rats used.

plots of specific binding were linear in both the control and $\mathrm{Mg}$-deficient rat aortas (data not shown), indicating a single class of binding sites. Calculated $K_{D}$ and $B_{\max }$ values are shown in Table 4 . There were no significant differences in $K_{D}$ and $B_{\max }$ values between the control and $\mathrm{Mg}$-deficient rats. $\mathrm{K}_{\mathrm{D}}$ values in the presence of both $\mathrm{PE}$ and $\mathrm{H} 7$ were significantly larger than those in the presence of PE only as shown in Table 2.

The inhibitory effect of nifedipine on the specific binding of $\left[{ }^{3} \mathrm{H}\right] \mathrm{PN} 200-110$ in the presence of both $10 \mu \mathrm{M}$ PE and $10 \mu \mathrm{M} \mathrm{H} 7$ was examined in the control and $\mathrm{Mg}$ deficient rats. In $\mathrm{Mg}$-deficient rats, the $\mathrm{pK}_{\mathrm{i}}$ value for nifedipine decreased significantly from $9.54 \pm 0.04$ (Table $3)$ to $8.92 \pm 0.03(n=4)$ in the presence of both PE and H7. However, in control rats $(n=4)$, it was not significantly different from that obtained in the presence of PE only $(8.79 \pm 0.08$ vs. $8.69 \pm 0.07$ respectively, see Table 3 ).

\section{DISCUSSION}

The potentiated vascular contractile response to an $\alpha_{1}$ agonist, $\mathrm{PE}$, in the thoracic aorta isolated from rats with dietary $\mathrm{Mg}$ deficiency confirms our previous data (4). It has been shown that PE causes the contractile response in rat aorta via extracellular $\mathrm{Ca}^{2+}$-entry, intracellular $\mathrm{Ca}^{2+}$ release and the increase to $\mathrm{Ca}^{2+}$-sensitization of contractile elements in smooth muscle cells $(10-12)$. The contractile response to PE of thoracic aorta in $\mathrm{Ca}^{2+}$-free PSS showed no significant difference between the control and
Mg-deficient rats (A. Nishio and H. Sakaguchi, unpublished data). These results suggest that the enhanced contractile response to $\mathrm{PE}$ in thoracic aorta isolated from $\mathrm{Mg}$-deficient rats depends mainly on $\mathrm{Ca}^{2+}$-entry via the stimulation of $\alpha_{1}$-adrenoceptors. The possibility that changes in the L-type $\mathrm{Ca}^{2+}$ channel were involved in the enhanced contractile response to PE during Mg-deficiency was examined using nifedipine (an L-type $\mathrm{Ca}^{2+}$ channel antagonist) (13). Nifedipine depressed PE-induced contraction of aortas in both $\mathrm{Mg}$-deficient rats and controls, and the degree of depression was significantly greater in the $\mathrm{Mg}$-deficient rats. These results suggest that functional changes in the L-type $\mathrm{Ca}^{2+}$ channel may occur during $\mathrm{Mg}$-deficiency and participate in the enhancement of PE-induced contraction. However, contractions induced by $60 \mathrm{mM} \mathrm{KCl}$ and the inhibitory effect of nifedipine on these contractile responses were unchanged during $\mathrm{Mg}$-deficiency. These results clearly show that enhanced vasoconstriction and increased susceptibility to nifedipine are observed in $\mathrm{Mg}$-deficient rat aorta during $\alpha_{1}$-adrenoceptor stimulation, but not during membrane depolarization.

In vascular smooth muscle stimulated by an $\alpha_{1}$-agonist, it has been reported that the functions of the L-type $\mathrm{Ca}^{2+}$ channels are controlled by membrane depolarization (14-16), by direct coupling of pertussis toxin-sensitive $G$ protein $(17,18)$ or by channel phosphorylation by protein kinase $C(19,20)$. It is well known that stimulation of $\alpha_{1}$ adrenoceptors activates phospholipase $C$ and produces diacylglycerol which is an activator of protein kinase $\mathrm{C}$ (11). Recently, it has been shown that a pertussis toxin-insensitive $G$ protein is involved in the activation of phospholipase $C$ by norepinephrine stimulation (19). Pertussis toxin did not alter PE-induced contraction in rat thoracic aorta in this study (A. Nishio and H. Sakaguchi, unpublished data). Therefore, the effects of $\mathbf{H} 7$ (a protein kinase $\mathrm{C}$ inhibitor) (21) on the contractile response to PE and on the inhibitory effects of nifedipine were investigated. PE-induced vasoconstriction and the inhibitory effects of nifedipine were not significantly different in $\mathrm{Mg}$-deficient rats and controls in the presence of H7. Hidaka and Kobayashi (21) have shown that $\mathrm{H} 7$ inhibits also cyclic AMP-and cyclic GMP-dependent protein kinases. In vascular smooth muscles, however, it has been shown that the activation of cyclic AMP- and cyclic GMP-dependent protein kinases depresses the voltage dependent $\mathrm{Ca}^{2+}$ channel current and that of protein kinase $\mathrm{C}$ increases it (22-24). Therefore, PE-induced contraction in $\mathrm{Mg}$ deficient rats may be enhanced through the activation of protein kinase $\mathrm{C}$.

Our previous study (4), using $\left[{ }^{3} \mathrm{H}\right] \mathrm{PN} 200-110$ specific binding to rat aorta membranes, showed that the enhanced contractile response to PE during Mg-deficiency 
might depend on an increase in the number of L-type $\mathrm{Ca}^{2+}$ channels. However, it is well known that L-type $\mathrm{Ca}^{2+}$ channels exist in different conformational states and that dihydropyridines have a high affinity for the inactivated state $(25,26)$. Therefore, we tried to characterize the L-type $\mathrm{Ca}^{2+}$ channels using $\left[{ }^{3} \mathrm{H}\right] \mathrm{PN} 200-110$ binding to aortic strip in the presence of PE. It has been reported that both membrane depolarization and the stimulation of $\alpha_{1}$-adrenoceptors increases the binding affinity of dihydropyridines without changing the number of dihydropyridine receptors in vascular smooth muscles $(7,16$, $20,27)$. Similar results were obtained in the present study (Table 2), although the $K_{D}$ value obtained from $\mathrm{Mg}$ deficient rats was significantly smaller than that from controls in the presence of $\mathrm{PE}$, but not $\mathrm{KCl}$. Also, potentiation of the inhibitory effects of nifedipine on $\left[{ }^{3} \mathrm{H}\right] \mathrm{PN} 200$ 110 binding in $\mathrm{Mg}$-deficient rats was observed only during the stimulation of $\alpha_{1}$-adrenoceptors. The $\mathrm{pK}_{\mathrm{i}}$ values for nifedipine (9.54 \pm 0.04$)$ obtained from the binding studies were close to the $\mathrm{pIC}_{50}(9.21 \pm 0.23)$ values obtained from the functional studies. These results indicate that the increased affinity of $\left[{ }^{3} \mathrm{H}\right] \mathrm{PN} 200-110$ binding to the aortic strip may play an important role in the enhancement of PE-induced contraction during $\mathrm{Mg}$-deficiency.

It has been shown that activation of protein kinase $\mathrm{C}$ by the stimulation of $\alpha_{1}$-adrenoceptors modulates $\left[{ }^{3} \mathrm{H}\right] \mathrm{PN} 200-110$ binding to voltage-dependent $\mathrm{Ca}^{2+}$ channels independently of a separate modulation by membrane depolarization (20). Therefore, the effects of $\mathbf{H} 7$ on the increased affinity of $\left[{ }^{3} \mathrm{H}\right] \mathrm{PN} 200-110$ binding and on the inhibitory effects of nifedipine on $\left[{ }^{3} \mathrm{H}\right] \mathrm{PN} 200-110$ binding were examined. In the presence of both $\mathrm{PE}$ and $H 7$, the $K_{D}$ and $p K_{i}$ values for nifedipine obtained from $\mathrm{Mg}$-deficient rats were not significantly different from those in the controls (Table 4). These results strongly suggest that protein kinase $\mathrm{C}$ is involved in the increased affinity of $\left[{ }^{3} \mathrm{H}\right] \mathrm{PN} 200-110$ binding to PE-stimulated aorta isolated from $\mathrm{Mg}$-deficient rats. However, the $\mathrm{K}_{\mathrm{D}}$ values obtained in the presence of both $\mathrm{PE}$ and $\mathrm{H} 7$ were significantly smaller than those obtained in the resting state in both groups. These results clearly indicate that another transduction mechanism is involved in the increased affinity of [ $\left.{ }^{3} \mathrm{H}\right] \mathrm{PN} 200-110$ binding via the stimulation of $\alpha_{1^{-}}$ adrenoceptors. Morel and Godfraind (16) have shown that the increase in affinity of $\left[{ }^{3} \mathrm{H}\right] \mathrm{PN} 200-110$ by the stimulation of $\alpha_{1}$-adrenoceptors by $10 \mu \mathrm{M}$ norepinephrine may depend on membrane depolarization, which is comparable to $25 \mathrm{mM} \mathrm{KCl}$ in rat aorta. One could speculate that the $K_{D}$ values obtained in the presence of both $P E$ and $H 7$ (Table 4) are modified by membrane depolarization in both groups. There is a possibility that in rat aorta, the increased affinity of $\left[{ }^{3} \mathrm{H}\right] \mathrm{PN} 200-110$ binding following the stimulation of $\alpha_{1}$-adrenoceptors may be due to: 1) mem- brane depolarization (which is unchanged in Mg-deficiency) and 2) activation of protein kinase $C$ (which is independent of membrane potential). Only the change of channel function modulated by protein kinase $\mathrm{C}$ via the stimulation of $\alpha_{1}$-adrenoceptors may participate in the enhanced contractile response to PE in thoracic aortas during $\mathrm{Mg}$-deficiency.

The observation that changes in $\left[{ }^{3} \mathrm{H}\right]$ dihydropyridine binding sites occur in some pathological states (hypertension, cardiomyopathy) has led some workers to suggest that alterations in $\mathrm{L}$-type $\mathrm{Ca}^{2+}$ channels may play a crucial role in the etiology of these diseases $(28,29)$. However, few reports have described the relationship between the characteristics of $\mathrm{Ca}^{2+}$ channels stimulated by agonists and agonist-induced functional changes in these pathological states. The present study does not clarify how protein kinase $C$ participates in the enhancement of the contractile response to $\mathrm{PE}$ in thoracic aortas isolated from $\mathrm{Mg}$ deficient rats. Therefore, further studies using a direct protein kinase $\mathrm{C}$ activator, such as phorbol 12-myristate 13acetate, are needed.

In conclusion, the present results indicate that modulation of $\mathrm{L}$-type $\mathrm{Ca}^{2+}$ channels via the stimulation of $\alpha_{1^{-}}$ adrenoceptors participates in enhanced vasoconstriction and increased susceptibility to nifedipine in aortas isolated from rats with dietary $\mathrm{Mg}$ deficiency. The $\mathrm{H} 7$-sensitive mechanisms may play an important role in these phenomena.

\section{REFERENCES}

1 Altura BM, Altura BT, Carella A, Gebrewold A, Murakawa T and Nishio A: Magnesium-calcium interaction in contractility of vascular smooth muscle: Magnesium versus organic calcium channel blockers on myogenic tone and agonist-induced responsiveness of blood vessels. Can J Physiol Pharmacol 65, $729-745$ (1987)

2 Nishio A, Ishiguro $S$ and Matsumoto $M$ : Ex vivo study of the vascular reactivity to some vaso-active agents in isolated thoracic aorta from $\mathrm{Mg}$-deficient rats. Magnesium Res 1, 169-175 (1988)

3 Nishio A, Ishiguro S, Shimonishi I and Hirota A: Enhanced contractile response to noradrenaline and calcium influx in thoracic aorta isolated from dietary magnesium deficient rats. Magnesium Res 2, 173-178 (1989)

4 Sakaguchi $H$, Ishiguro $S$ and Nishio $A$ : Enhanced contractile response to phenylephrine and increased density of $\left[{ }^{3} \mathrm{H}\right] \mathrm{PN} 200$ 110 binding sites in thoracic aorta isolated from $\mathrm{Mg}$-deficient rats. Jpn J Pharmacol 61, Supp I, 118P (1993)

5 Spedding $\mathbf{M}$ and Paoletti $\mathbf{R}$ : Classification of calcium channels and the sites of action of drugs modifying channel function. Pharmacol Rev 44, 363-376 (1992)

6 Furchgott RF and Zawadzki JV: The obligatory role of endothelial cells in the relaxation of arterial smooth muscle by acetylcholine. Nature 288, 373-376 (1980)

7 Morel N and Godfraind T: Prolonged depolarization increases 
the pharmacological effect of dihydropyridines and their binding affinity for calcium channels of vascular smooth muscle. $\mathbf{J}$ Pharmacol Exp Ther 243, 711-715 (1987)

8 McPherson GA: Analysis of radioligand binding experiments. A collection of computer programs for IBM PC. J Pharmacol Methods 14, 213-228 (1985)

9 Sakaguchi H, Sakaguchi R, Ishiguro S and Nishio A: Beneficial effects of calcium antagonist, nifedipine, on death and cardiovascular calcinosis induced by dietary magnesium deficiency in adult mice. Magnesium Res 5, 121-125 (1992)

10 Godfraind T, Miller RC and Lima JS: Selective $\alpha_{1^{-}}$and $\alpha_{2^{-}}$ adrenoceptor agonist-induced contraction and ${ }^{45} \mathrm{Ca}$ fluxes in the rat isolated aorta. Br J Pharmacol 77, 597-604 (1982)

11 Minneman KP: $\alpha_{1}$-Adrenergic receptor subtypes, inositol phosphates, and sources of cell $\mathrm{Ca}^{2+}$. Pharmacol Rev 40, 87-119 (1988)

12 Karaki $H$, Sato $\mathrm{K}$ and Ozaki $\mathrm{H}$ : Different effects of verapamil on cytosolic $\mathrm{Ca}^{2+}$ and contraction in norepinephrine-stimulated vascular smooth muscle. Jpn J Pharmacol 55, 35-42 (1991)

13 Hosey MM and Lazdunski M: Calcium channels: molecular pharmacology, structure and regulation. J Membr Biol 104, $81-105$ (1988)

14 Nelson MT, Standen NB, Brayden JE and Worley JF III: Noradrenaline contracts arteries by activating voltage-dependent calcium channels. Nature 336, 382-385 (1988)

15 Haeusler G and De Peyer J-E: Rabbit aorta: electrical properties and agonist-induced depolarization. Eur J Pharmacol 166, 175-182 (1989)

16 Morel $\mathrm{N}$ and Godfraind T: Characterization in rat aorta of the binding sites responsible for blockade of noradrenaline-evoked calcium entry by nisoldipine. Br J Pharmacol 102, 467-477 (1991)

17 Nichols AJ, Motley ED and Ruffolo RR $\mathrm{J}_{\mathrm{r}}$ : Effect of pertussis toxin treatment on postjunctional alpha-1 and alpha-2 adrenoceptor function in the cardiovascular system of the pithed rat. 3 Pharmacol Exp Ther 249, 203-209 (1989)

18 Rakotoarisoa L, Mironneau C, Sayet I and Mironneau J: Guanine nucleotide-binding proteins modulate desmethoxyverapamil binding to calcium channels in vascular smooth muscle. J Pharmacol Exp Ther 259, 164-168 (1991)

19 Loirand G, Pacaud P, Mironneau C and Mironneau J: GTP- binding proteins mediate noradrenaline effects on calcium and chloride currents in rat portal vein myocytes. J Physiol (Lond) 428, 517-529 (1990)

20 Mironneau C, Rakotoarisoa L, Sayet I and Mironneau J: Modulation of $\left[{ }^{3} \mathrm{H}\right]$ dihydropyridine binding by activation of protein kinase $\mathrm{C}$ in vascular smooth muscle. Eur $\mathrm{J}$ Pharmacol (Mol Pharmacol Sec) 208, 223-230 (1991)

21 Hidaka $\mathrm{H}$ and Kobayashi R: Pharmacology of protein kinase inhibitors. Annu Rev Pharmacol Toxicol 32, 377-397 (1992)

22 Sperelakis $\mathrm{N}$ and Ohya Y: Regulation of calcium slow channels in vascular smooth muscle cells. In Ion Channels of Vascular Smooth Muscle Cells and Endothelial Cells, Edited by Sperelakis N and Kuriyama H, pp 27-38, Elsevier Sci Publ Co, New York (1991)

23 Ousterhout JM and Sperelakis N: Cyclic nucleotides depress action potentials in cultured aortic smooth muscle cells. Eur $\mathbf{J}$ Pharmacol 144, 7-14 (1987)

24 Fish RD, Sperti G, Colucci WS and Clapham DE: Phorbol ester increases the dihydropyridine-sensitive calcium conductance in a vascular smooth muscle cell line. Circ Res 62, 1049-1054 (1988)

25 Bean BP: Nitrendipine block of cardiac calcium channels: High-affinity binding to the inactivated state. Proc Natl Acad Sci USA 81, 6388-6392 (1984)

26 Cohen $\mathrm{CJ}$ and McCarthy RT: Nimodipine block of calcium channels in rat anterior pituitary cells. J Physiol (Lond) 387, 195-225 (1987)

27 Dacquet C, Loiland G, Rakotoarisoa L, Mironneau C and Mironneau $\mathrm{J}:(+)-\left[{ }^{3} \mathrm{H}\right]-\mathrm{PN} 200-110$ binding to cell membranes and intact strips of portal vein smooth muscle: characterization and modulation by membrane potential and divalent cations. Br J Pharmacol 97, 256-262 (1989)

28 Chatelain P, Demol D and Roba J: Comparison of [ $\left.{ }^{3} \mathrm{H}\right]$ nitrendipine binding to heart membranes of normotensive and spontaneously hypertensive rats. J Cardiovasc Pharmacol 6, 220-223 (1984)

29 Wagner JA, Reynolds IJ, Weisman HF, Dudeck P, Weisfeldt ML and Snyder SH: Calcium antagonist receptors in cardiomyopathic hamster: selective increased in heart, muscle, brain. Science 232, 515-518 (1986) 